\title{
Truth or Treachery? Questioning Authenticity and Invisibility in Travel and Translation
}

\author{
SASWATI SAHA
}

This paper will draw a comparison between a traveller and a translator since both deal with a world of otherness which they strive to bring to the readers. Both the traveller and the translator also make an effort to convince the readers about the authenticity of their narrative. This becomes important because in travel writing and in translations the narrative is mediated through the subjective presence of a travel writer or a translator. As such the activities are considered notoriously manipulative since the act of (re)presenting (an)other depends majorly on how the travellertranslator deploys language. It is in telling the tales of his experience that a traveller-translator involves his own subjective understanding of the lands and cultures which he sees and experiences exclusively in his own way. But this subjectivity of the traveller or translator gets suppressed under the pretext of what Lawrence Venuti calls "fluency ideal". Thus a travellertranslator has to create an impression on the readers that the stories they are reading are exactly the ones that are experienced by the denizens of the "other" world otherwise $\mathrm{s} / \mathrm{he}$ is regarded as treacherous, a threat to the native culture and language contaminating it with foreign elements. This is why they suffer from an anxiety and a compulsion to establish the veracity of their account. This paper deals with a translation of Gulliver's Travels in Bengali titled Apūrba Deś Bhraman, the first part of which was named Abākpūrī Darśan (1876), an example of a translated (pseudo) travel-writing to show how a travellertranslator deals with the issue of visibility and language. Is it possible for the translator to become visible? This paper shows how the narrative itself becomes a space for the travellertranslator in which he reclaims his subjectivity deploying language and thereby dealing with the issue of authenticity and invisibility.

Keywords: translator, traveller, authenticity, invisibility, subjectivity.

Travellers bring a world of otherness to readers and strive for an authenticity required for their self-protection. So does a translator. Both travel writing and translations are re-writing and the narrative is mediated through the subjective presence of a travel writer or a translator. Both the activities are largely 
manipulative since the act of (re)presenting (an)other depends majorly on how the traveller-translator deploys language. Albeit language belongs to the traveller-translator, it is presented in a way that it is capable enough of handling the otherness of "facts" that the readers are interested in reading. In fact, the translator is involved in a journey, and much like the traveller, he is travelling to a land of tales and bring those for their readers. Etymologically 'to translate' come from the Latin verb "traducer"-meaning to travel from one place to another. "Traducer" means to lead across, transfer or carry over from trans which means across or beyond. The word thus has the essence of two words: "trans"- meaning one place to another and "ducere"- meaning guide or lead. ${ }^{1}$ The traveller, on the other hand, is a translator himself who translates his experiences on a voyage into words, thereby leading and guiding others, who are at home, to lands far and wide he had been. The difficulty and pain involved in the process is embedded etymologically in the word "travel" which finds its root in the word "travail" which means "to toil, to suffer, to put a painful effort or to labour". The semantic development was perhaps based on the notion of "going on a difficult journey," but it may also refer to the difficulty of any journey in the Middle Ages. ${ }^{2}$ This corresponds to Michael Cronin's nomadic theory of translation which proposes the "translator-nomad as an emblematic figure by demonstrating what translation can tell us about nomadism and what nomadism can tell us about translation and how both impinge on contemporary concerns with identity" (Gambier \& van Doorslaer 2013: 194).

It is in telling the tales of his experience that a traveller-translator involves his own subjective understanding of the lands and cultures which he sees and experiences exclusively in his own way. This is much like the subjectivity of the translator through which a source text has to pass in order to become the target text. But this subjectivity of the traveller or translator gets suppressed under the pretext of what Lawrence Venuti calls "fluency ideal". ${ }^{3}$ This is how the publishing industry claims to provide the target language readers with the authentic version of the text; as if the readers are reading the "original" or that they are themselves visiting a land unknown. Since the focus of a publishing house is that of selling the book, their mantra is, as Susan Bassnett points out, that the "truth" of both a translation and a travel-writing "depends not only on how the story is told, but also on reader's desire to believe the teller" (Bassnett 2004: 67). The judgement of the publishing industry of a translated text is essentially "product-oriented" and not "process-oriented". Instead of

\footnotetext{
${ }^{1}$ See https://www.etymonline.com/word/transducer

${ }^{2}$ See https://www.etymonline.com/search?q=travail

3 As discussed in Lawrence Venuti's The Translator's Invisibility: A History of Translation, published by Routledge in the year 1995. Venuti writes, "The more fluent the translation, the more invisible the translator, and presumably, the more visible the writer or meaning of the foreign text."

${ }^{4}$ See Susan Bassnett's "Introduction" to the Translation Studies, London and New York: Routledge, 1980.
} 
focussing on what goes into the process of translation, their assessment is mostly based on value judgement of the translated texts as either "good" or "bad". A "good" translation is one which successfully domesticates the cultural 'other' of the source text and naturalizes it with the local vocabulary and the cultural nuances of the target language. It will therefore provide the target language readers with the comfort of their ever known indigenous language culture to which the source text will travel.

Thus a traveller/travel-writer has to create an impression on the readers that the stories they are reading are exactly the ones that the denizens of the "other" world experience. Therefore, the traveller or the translator exists, yet they do not exist. They are reduced to being invisible agents being caught up in a network comprising of the various players of the publishing industry. The case is no different in case of a translator. A publisher or an editor chooses the works and commissions translations, pays the translator and often dictate the methods that the translator must follow while translating. Therefore, what happens is a complete suppression of subjectivity. The translator is bereaved of his own work and by inflicting this pain on him, the publisher established ownership over both the translator and his work.

Lawrence Venuti, in his famous work The Translator's Invisibility, quotes Norman Shapiro to explain the popular conventional ideas regarding the role of the translator in the process of translation. Shapiro points out that a translation is considered "good" when the subjectivity of the translator gets completely erased. Shapiro argues that a translation should be transparent like a view through a crystal clear pane of glass. Any bubble or spot on it will attract attention, thereby inhibiting the view (Venuti 1995: 1). The creative and imaginative self of the translator is like stains or bubbles on the glass which might interfere with the readers' thoughts and coerce them to reflect on the stains instead of looking through it. The eye, in order to view the original should be able to look beyond and through the window pane. The same applies to that of the traveller's account. His imagination and subjective analysis are the bubbles on a window pane that affects the process of looking through it and hence are most undesirable. Therefore, although he is the one who brought the stories home, he is nothing but a mere reporter, who reports exactly what he sees.

Emma Wagner in reply to Andew Chesterman's question regarding the conspiracy of the publishing world that keeps a translator an invisible agent, in a chapter aptly titled, "I translate, therefore I am not" says:

Yes, we (translators) feel that we are not recognized; but no, we don't think that having our names on our translations would solve the problem. Really there are two problems: lack of appreciation (which is not the same thing as personal visibility), and lack of professional recognition... Our job is to be invisible and neutral, not to distort the original text by imposing our own personality on it (Chesterman \& Wagner 2002: 27-28). 
The creativity and imagination of a translator is never given due credit, he is kept out of sight; the work is never considered his own; often he has to work within the guidelines provided by the publishing house; and in most of the cases, he is denied even a proper copyright. The publishing industry fails to recognise the translator as a co-author or a co-creator of a text in its own rights and therefore the authority of the work is vested with the author. It is the author who decides on the publication and translation of the texts. ${ }^{5}$ Thus the task of the translator is reduced to the status of a "derivative work". This denigration results in the translators becoming more mindful about the quality of their work of translation and tries to fit them well into the existing literary conventions of the target culture.

In case of travel writings by travellers, different strategies are used by them to ensure the veracity of their accounts by establishing the idea of an authoritative origin that lies behind the text, i.e., the journey. ${ }^{6}$ Bassnett writes,

For travel writers need a source, and that source is generally presumed to be the journey that took place before the writing began. The journey is therefore the original text that is later inscribed in the written work that recounts what happened during the journey, and because travel writing is premised on the idea of a voyage that actually happened, it is essential to ensure the readers believe the author (Bassnett 2004: 68).

The details of the places, people, and their cultural practices are a strategy to make the readers believe the stories. These also prove the authority of the traveller and hint at his experience of interacting with people and culture outside his own land.

The next section of the paper will deal with an example of a translated travel-writing to show how a traveller-translator deals with the issue of visibility and language. Is it possible for the translator to become visible? If yes, then how? The paper will attempt an analysis of a translation of Gulliver's Travels in Bengali titled Apūrba Deś Bhraman, the first part of which was named Abākpūrī Darśan (1876) to see how in a translated travel narrative, the self of the traveller and the translator merge to become one, who then deals with the issue of visibility deploying language to describe the subjective experience. The narrative itself provides the space and scope for the traveller-translator to reclaim the suppressed subjectivity. He then through the tactful use of language makes to convince the readers of the authenticity of the text.

Gulliver's Travels is a text of Irish origin that travelled to India, via England. In spite of the text's popularity of being a political text, one of the

\footnotetext{
${ }^{5}$ Lawrence Venuti has discussed in detail the lack of legal recognition of a translator visa-vis his translation in The Translator's Invisibility.

${ }^{6}$ See Susan Bassnett's essay “Travelling and Translating” (2004) for a detailed discussion on this.
} 
key factors to be noted in the translation is that Swift's political satire gets rendered and represented as a deś bhramaner kāhin̄̄ or a travel narrative. But the travel described is not the stuff of epic or romance, it is rather a struggle, harping on some very pertinent concerns of travellers. The traveller in the book is a Bengali man who has embarked upon a journey. The "I" of Gulliver is modified and internalised by the translator who now acts, thinks and writes according to the necessity of the new 'I'. The title of the book suggests that it is narrating an 'apürba' (wonderful/ unprecedented) travel experience, something that has never happened before and is therefore unheard of. The word ' $a b \bar{a} k$ ' (wonder) refers to the wonder attached to such travel experiences where one encounters the cultural other which in return helps to define the self. The concept of wonder depicted through the word $a b \bar{a} k$ (wonder) was typically applied by European travellers to the Orient, thereby reminding the readers that he was an outsider. His presence is necessary mobile and his mobility is contrasted with the immobility of the inhabitants of the remote regions he visits. The stranger comes and affects the world of the host, but he will move on whereas they will stay put. In fact, there is a constant urge of returning home. 'Darśan' or seeing refers to an ethnographic study through which the traveller transformed their subjugation into empowerment. Moreover, his narrative is a translation of what he sees and how he interprets what he sees. The traveller saw and thereby constructed an eye (also 'I') that gave the traveller a point of view from which he could now write back to the colonizer.

The most important strategy that sets this bhraman kāhinī (travel narrative) apart from the other travel narratives is the preoccupation with forms of travel and travel experiences that are arduous, unpleasant or downright dangerous. The traveller experiences a shipwreck and lands up in a remote corner of the world which has never been heard of. There is a sense of exploration and the traveller of being a first time visitor. But all these are achieved at the cost of the suffering of the traveller. The notion of suffering in travel evoked a romance and gave an importance to the persona of the traveller. This self-fashioning differentiated him from other contemporary tourists. Emphasis on the misadventure gave them a kind of heroic demeanour which made them active agents in the journey they have undertaken and not just passive recorders of facts and events. The protagonist in the story refers to his previous travels which too were troublesome and were full of obstacles. This not only provides him with the position of an experienced traveller but also confirms his bravery and skills to deal with the roughness of sea voyages.

The suffering of the traveller hence becomes a personal experience that was to be publicly enjoyed. The readers enjoy the contrast between their own security and the distress s/he is reading. The necessity of such unprecedented troubles at sea in a travel narrative has been aptly described by Caroline Alexander where she writes, "If we had everything we wanted we should have no privations to write about and that would be serious loss to the 
"book". Privations make a book sell like anything" (Alexander 1999: 195). What she is referring to is the appetite of the readers for description of acute suffering and frightful mishaps. The misadventure is a pre-requisite for the feelings of pain for creating the much necessary romantic situation. The pleasure of discovering territories provides a subtle logic linking suffering to empirical knowledge. Misadventure also provided a route to visionary experience and literary authority.

The protagonist declares at the very beginning that he has an affinity towards the learning of different languages. Owing to his sharp memory, he could master languages of the places he had been to as a sailor. He took the learning of languages as a corroborative act along with understanding of various socio-cultural practices of the people he came across. Language is intricately linked with the culture of a community and the key to gaining knowledge about a community is only possible through learning its language. Later when he is in $A b \bar{a} k p \bar{u} r \bar{r}$ (wonderland) he learns the language of the place. As Michael Cronin suggests, this is the most important aspect of travel because in a journey companionship demands speech, hence making the question of human speech inescapable (2010: 334). The language in which the native inhabitants speak apparently seems completely gibberish to the Bengali readers bearing not even the remotest resemblance with the languages they are familiar with. The obscurity of the language provides an exotic feel to the land which is equally remote. Cronin suggests that the obscurity of the language relates to the obscurity of the places, places that are remote or marginal. The peculiarity or the endangered state of the language becomes conflated with the physical peripherality of the speakers (2010: 336).

The narrator fails to comprehend everything that the natives speak. Language allows meaning to circulate within the speakers of a community and allows signification to travel across the community. It has an indispensable relation with the act of travel since writing of a travel narrative which essentially entails translation is only possible because of this circulatory nature of language. But the very language that enables communication across cultures can be at the same time inclusive for its speakers, thereby excluding outsiders. Language then becomes essentially "non-circulatory" which according to Cronin makes interlingual translation both necessary and problematic (2010: 336). The traveller has to translate in order to make meanings circulate but again is made aware that meaning often resists traffic. The Bengali Gulliver figure tries to comprehend the gestures of the tiny people around him when language evades him. But with the lapse of time and close observation, he starts guessing the meaning of the words. As the narrative progresses, we learn that the king of $A b \bar{a} k p \bar{u} r \bar{\imath}$ (wonderland) appoints six teachers to teach the traveller the local language. This is the opportunity for him to learn the language to engage with it and interpret the realities of the native culture both for him and his readers. His stance as a 
translator is that of "representational". ${ }^{7} \mathrm{He}$ does not attempt to impact upon the language of the natives, neither does his understanding of his own language and culture gets impacted upon through the interactions, but the translation is solely for the purpose of representation. The effort made by the traveller to learn the language is also a proof of his commitment as a true traveller-translator. He is not merely reducing the place he is travelling to into a set of landscape pictures described in the major language of the traveller (an example of spatial translation as suggested by Cronin), but invests time in learning the language with earnestness to develop translational skills (Cronin's idea of temporal translation). ${ }^{8}$

The first proper linguistic communication between the traveller and the natives (the king) is given in Bengali. The narrator provides the readers a disclaimer that albeit the conversation took place in the language of the natives, he has translated it into Bengali for the benefit of his readers. At this point in the text, the translator makes a clear statement on the methodology of his translation. His allegiance is clearly towards his readers and it is for them that he will "domesticate" the source text (language and culture of the land) to cater to the taste and comprehensibility of his readers. He is at the same time aware of the fact that this might compromise the authenticity of the translation. Ergo, to make his narrative more believable, he says, not all of the conversation happened in spoken language, but also involved communication through gestures. It is through this assertion, the translator is accomplishing two tasks: firstly by choosing the methodology of domestication, he carves a niche for himself in the narrative, thereby making a space in which he reclaims his subjectivity deploying language of his choice based on his subjective understanding and his convenience, hence rescuing him from invisibility. Secondly, he wins the faith of his readers by being on their side, and promises to communicate to them all that he learns and experiences. From here on the translator communicates every event that happens and he experiences in the land of his travel in Bengali only finding equivalent culturally specific items from his land. He thereby captures the uniqueness of the culture of $A b \bar{a} k p \bar{u} r \bar{i}$ within a framework of relevance for the ease of comprehensibility. He, in the process, grants himself the liberty to choose the degree of relevance and equivalence, thus reminding his existence between

\footnotetext{
7 According to Michael Cronin, language contact has two distinct impacts: representational and instrumental. "The representational impact", he writes, "relates to the ability of the travel writer to translate the thoughts, values and experiences of others, into the language of the writer. In this case however strong the take is on the other culture, access point to another language is translation... The instrumental impact is the effect of the travel itself on the language communities." This happens when the traveller is the speaker of the major language of the world. This leads to major lingucides where the minor language speakers of the world are coerced into translating themselves in the dominant host languages (2010: 334-335).

${ }^{8}$ See Michael Cronin's "Knowing one's place: Travel, difference and translation" in Translation Studies (2010) pp- 339.
} 
the source (the journey to the land) and the target (the readers). Susan Bassnett in her essay "Travel and Translation" writes:

The translator explores a text written in another time and place and brings back his or her version of that exploratory process in the form of a translation. The travel writer produces a different kind of translation, a version of a journey that he or she claims to have undertaken. Both processes involve complex relationships with readers also. The reader is required to make a leap of faith and to trust both travel writer and translator. The assumption when reading a translation is that there is another, original text somewhere else which the translator has 'faithfully' reproduced. The assumption when reading a travel account is that the writer is 'faithfully' telling the story of an actual journey (2004: 70).

It is this meeting point of the traveller-translator and his readers lay the success of a travel narrative. But this complete "faithfulness" is nonetheless mediated by the subjective presence of the traveller-translator who makes his existence visible through the way he constructs the narrative, the choices he makes regarding what is to be related to his readers and how, whether to retain the foreignness in the narrative or to render all his experience in the language of his readers.

Travel and translation are therefore acts of re-penning through which the traveller-translator forges his subjectivity thereby overcoming the pain of invisibility. Both translator and traveller were once regarded as treacherous as they were a threat to the native culture and language contaminating it with foreign elements. But it is the narrative space and through certain techniques of narrativising that they claim spaces for their own doing away with any attempt of eradicating their subjectivity.

\section{References}

Apūrba Deś Bhramaṇ Part I Abākpūrī Darśan. 1876. Kolkata: Majumdara's Depository.

ALEXANDER, CAROLINE. 1999. The Endurance: Shackleton's Legendary Antarctic Expedition. New Tork: Knopf.

BASSNETT, SUSAN. 2004. Travelling and Translating. World Literature Written in English 40(2). 66-76. DOI: 10.1080/17449850408589391.

Chesterman, ANDREW and EMMA WAGNer. 2002. Can Theory Help Translators?: A Dialogue between the Ivory Tower and the Wordface. New York: Routledge.

CODELL, JULIE F. 2007. Reversing the Grand Tour: Guest Discourse in Indian Travel Narratives. Huntington Library Quarterly, 70(1). 173-189. 
Translation, Nation and Knowledge Society

Cronin, Michael. 2010. Knowing one's place: Travel, difference and translation. Translation Studies 3(3). 334-348. DOI: 10.1080/14781700. 2010.496932.

GAMBIER, YVES and LUC VAN DOORSLAER. 2013. Handbook of Translation Studies Volume 4. Amsterdam/ Philadelphia: John Benjamins Publishing Company.

LENNON, JOSEPH. 2004. Irish Orientalism: A Literary and Intelletual History. New York: Syracuse University Press.

SEN, SimONTI. 2005. Travels to Europe: Self and Other in Bengali Travel Narratives, 1870-1910. New Delhi: Orient Longman.

VENUTI, LAWRENCE. 1995. The Translator's Invisibility: A History of Translation. London and New York: Routledge.

YoungS, TIM. 2013 The Cambridge Introduction to Travel Writing. New York: Cambridge University Press. 